Authors: HJ Kloppers and GJ Pienaar

\title{
THE HISTORICAL CONTEXT OF LAND REFORM IN SOUTH AFRICA AND EARLY POLICIES
}

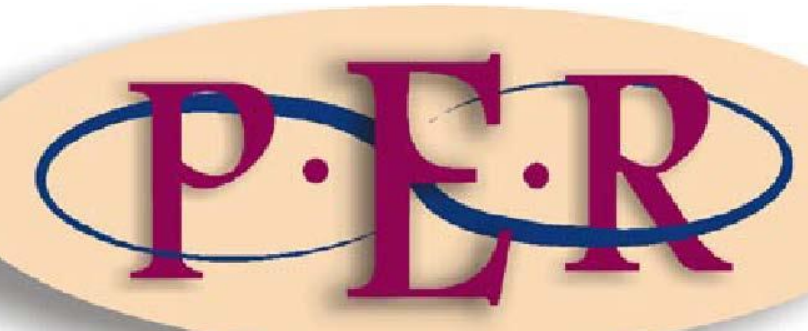

2014 VOLUME 17 No 2 


\section{THE HISTORICAL CONTEXT OF LAND REFORM IN SOUTH AFRICA AND EARLY POLICIES}

\section{HJ Kloppers and GJ Pienaar*}

\section{Introduction}

Post-apartheid South Africa faces a variety of challenges that emanated from the injustices caused by apartheid. One of the earliest challenges faced by the first democratically elected government was how to address the unequal distribution of land in the country. The South African government has shown commitment to eradicate the inequalities and injustices of the past and has initiated a comprehensive land reform programme with a strong constitutional basis - a programme which has to date not been concluded - a programme consisting of three pillars namely: restitution, land redistribution and tenure security.

The constitutional basis for the land restitution programme is found in section 25(7) of the Constitution, ${ }^{1}$ which states that:

A person or community dispossessed of property after 19 June 1913 as a result of past racially discriminatory laws or practices is entitled, to the extent provided by an Act of Parliament, either to restitution of that property or to equitable redress.

Similarly, section 25(5) of the Constitution introduced the second pillar of land reform, which is commonly referred to as the land redistribution programme. In terms of this section the state is under the constitutional duty to take "reasonable legislative and other measures, within its available resources, to foster conditions which enable citizens to gain access to land on an equitable basis".

Henk J Kloppers. B Com (Law), LLB, LLM (PU for CHE), LLD (NWU), Post Graduate Diploma in Financial Planning (UFS). Senior Lecturer at the Faculty of Law North-West University Potchefstroom campus. Email: Henk.Kloppers@nwu.ac.za. Gerrit J Pienaar. B Jur et Com LLB LLD (PU for CHE).Professor at the Faculty of Law North-West University Potchefstroom campus. Email: Gerrit.Pienaar@nwu.ac.za.

1 Constitution of the Republic of South Africa, 1996 (hereinafter referred to as the Constitution). S 25 of the Constitution is generally referred to as the "property clause". 
Finally, tenure security is addressed through section 25(6) of the Constitution which states that:

A person or community whose tenure of land is legally insecure as a result of past racially discriminatory laws or practices is entitled, to the extent provided by an Act of Parliament, either to tenure which is legally secure or to comparable redress.

As a result of these constitutional obligations, the South African government embarked on an ambitious land reform programme was aimed at redistributing $30 \%$ of white-owned commercial agricultural land by 2014 to black South Africans and settling all claims for redistribution (almost 80000 ) by 2005 . To date, more than seven years after the initial target, all land claims have still not been settled and less than $10 \%$ of the redistribution target has been achieved by the state. This figure does not take into consideration land bought or acquired by means of private transactions. However, the slow pace of these two land reform programmes is not the only challenge faced by the programmes. ${ }^{2}$ It has been reported that more than $90 \%$ of agricultural land transferred in terms of these two programmes is not being used productively. ${ }^{3}$ This situation not only contributes to increasing levels of poverty and unemployment among these land reform beneficiaries, but also threatens food security. A factor that further compounds the crisis is the recent calls by some politicians inciting landless South Africans to illegally occupy land belonging to white farmers, creating a potentially explosive situation. It is evident that the challenges faced by the land reform programmes are in urgent need of attention.

Against this background, it must be noted that two of the three constitutionally endorsed land reform programmes refer to past racially discriminatory laws or practices which facilitated racial segregation. Most of these measures have been recorded and discussed extensively in textbooks and other publications. ${ }^{4}$ This article

For a discussion of the challenges facing the land reform programme, see Kloppers Improving Land Reform 60-64, 77-85.

SAPA 2010 www.politicsweb.co.za.

See Badenhorst, Pienaar and Mostert Law of Property 585-665, Carey Miller and Pope Land Title 313-455; Mostert, Pienaar and Van Wyk "Land" 1-261. 
provides a brief overview of some of the predominant legislation that brought about racial segregation, or apartheid as it became known generally. The aim of this article, within the context of this special edition on land reform, is to familiarize readers with the historical prelude that gave rise to the need for land reform in the new constitutional dispensation. The consideration of the historical context of land reform and the rights associated (for example those set out in section 25 of the Constitution) assists in interpreting land reform within its textual context. This position was supported by judge Yacoob in Government of the Republic of South Africa $v$ Grootboom ${ }^{5}$ where it was stated that "rights must be understood in their social and historical context". The following sections will provide historical context to land reform.

\section{Legislative framework for territorial segregation}

This section in no way attempts to provide an extensive historical background to the discriminatory laws and practices related to land which gave rise to the need for land reform. ${ }^{6}$ A very brief overview will be provided of the main legislative framework for the territorially segregationist policies and the initial policies formulated by the post-1994 government to address the issue of land reform. ${ }^{7}$

The then National Party government's strategy of territorial segregation, population resettlement and political exclusion was founded on a history of conquest and dispossession enforced through oppressive land laws. ${ }^{8}$ According to Van der Walt, ${ }^{9}$ South African

5 Government of the Republic of South Africa v Grootboom 20011 SA 46 (CC) para 22.

6 For a more complete overview of the historical situation which gave rise to the need for the current land reform programmes, see Badenhorst, Pienaar and Mostert Law of Property 586-590; Murray and Williams 1994 Review of African Political Economy 315-318; Mapadimeng 2003 Transformation 21-30; Robinson 1997 Brooklyn J Int'l L 468-481; Mostert 2002 SALJ 401-402. Although the aim of this paragraph is to give a brief overview of the historical context of land reform, it has been noted that "[t]he popular debate on land reform in South Africa is influenced far more by beliefs about this country's history than by plans for its future well-being" (CDE Land Reform 5).

$7 \quad$ For a discussion of pre-apartheid land ownership, see Feinberg 1995 Historia 48-63.

8 Murray and Williams 1994 Review of African Political Economy 316; Badenhorst, Pienaar and Mostert Law of Property 586. The strategy of territorial segregation was aptly described by Sachs 
land law has also been employed to entrench the political ideology of racial segregation by means of spatial separation of race groups, thereby creating a controversial body of statutory law which may be called apartheid law.

The effect of this racially-based segregation legislation was to force black people to be "perpetual tenants" 10 with very limited rights. The first of these racially based segregation laws was the Natives Land Act 27 of $1913,{ }^{11}$ which in the year of this special edition celebrates its centenary.

\subsection{The Natives Land Act 27 of 1913}

The Natives Land Act layed the foundation for apartheid and territorial segregation and, for the first time, formalised limitations on black land ownership. ${ }^{12}$ The Act introduced ethnic differentiation based on the mistaken belief that differentiation between dissimilar races was fundamentally desirable. ${ }^{13}$ According to section $1(1)$ of the Act

Except with the approval of the Governor-General -

J in Port Elizabeth Municipality v Various Occupiers 20051 SA 217 (CC) paras 9-10 as "a cluster of statutes ... gave a legal/administrative imprimatur to the usurpation and forced removal of black people from land and compelled them to live in racially designated locations. For all black people, dispossession was nine-tenths of the law. Residential segregation was the cornerstone of the apartheid policy. This policy was aimed at creating separate 'countries' for Africans within South Africa. Africans were precluded from owning and occupying land outside the areas reserved for them by these statutes ... Differentiation on the basis of race was, accordingly, not only a source of grave assaults on the dignity of black people. It resulted in the creation of large, well-established and affluent white urban areas co-existing side-by-side with crammed pockets of impoverished and insecure black ones. The principles of ownership of Roman-Dutch law then gave legitimation in an apparently neutral and impartial way to the consequences of manifestly racist and partial laws and policies".

$9 \quad$ Van der Walt 1990 De Jure 2.

10 Claxton 2003 Mich J Race \& L 538.

11 This act later became known as the Black Land Act. However, it should be noted that this act was originally promulgated as the Natives Land Act as per Gazette Extraordinary No 380 of 19 June 1913. Since this article provides an historical overview, the author will refer to the act's original title.

12 Robinson 1997 Brooklyn J Int'l L 472. For a discussion of the historical context of the Natives Land Act, see Wickins 1981 S Afr J Econ 105-129; Feinberg 1993 IJAHS 65-109. For a general discussion of land initiatives between 1913 and 1948, see Feinberg 2009 Journal for Contemporary History 39-61. The Natives Land Act, together with the Native Trust and Land Act (see the discussion of this Act in para 2.2) was widely regarded as one of the cornerstones of apartheid (Fenyes, Van Rooyen and Vink 1990 Development Southern Africa 583). 
a native shall not enter into any agreement or transaction for the purchase, hire, or other acquisition from a person other than a native, of any such land or of any right thereto, interest therein, or servitude thereover; and

a person other than a native shall not enter into any agreement or transaction for the purchase, hire, or other acquisition from a native of any such land or of any right thereto, interest therein, or servitude thereover.

From the wording of these sections, it is clear that the aim of the Act was to bring about territorial segregation based on race, where natives were prohibited from occupying or acquiring land. According to Davenport ${ }^{14}$ the Act "laid down an absolute barrier in law between black and non-black landholding". The aim of the Act was further strengthened by section $1(2)$ of the Act, which provided: ${ }^{15}$

From and after the commencement of this Act, no person other than a native shall purchase, hire or in any other manner whatever acquire any land in a scheduled native area or enter into any agreement or transaction for the purchase, hire or other acquisition, direct or indirect, of any such land or of any right thereto or interest therein or servitude thereover, except with the approval of the GovernorGeneral.

Any agreement concluded in contravention of this prohibition was $a b$ initio null and void $^{16}$ and any contravention of the Act was punishable by the imposition of a fine or imprisonment with or without hard labour, not exceeding six months. ${ }^{17}$ The Act further made provision for the establishment of a commission tasked with the identification of areas within which black people ${ }^{18}$ would not be permitted to acquire or hire land ${ }^{19}$ or any interest in land, ${ }^{20}$ as well as areas where persons other

According to $s 10$ of the Act, a person shall be deemed to hire land if "in consideration of his being permitted to occupy that land or any portion thereof (a) he pays or promises to pay to any person a rent in money; or (b) he renders or promises to render to any person a share of the 
than black people would be prohibited from acquiring or hiring land or any interest in land. ${ }^{21}$ Through the Act, scheduled areas were designated and in terms of the Act, an estimated $8 \%$ of South African land was reserved for black South Africans. ${ }^{22}$

The Act effectively prohibited sharecropping contracts ${ }^{23}$ between white landowners and black farmers, resulting in many black farmers losing a substantial portion of their income, which in turn resulted in further economic hardship for them. As a law based on racial segregation, it is clear why this piece of legislation was singled out in the redistribution programme as the effective starting point for apartheid. This Act represented the first step in effecting racially based segregation, a system which was furthered through the Native Trust and Land Act 18 of $1936 .^{24}$

\subsection{The Native Trust and Land Act 18 of 1936}

The Native Trust and Land Act made provision for the establishment of the South African Native Trust, a state agency to administer trust land, and "to be administered for the settlement, support, benefit, and material welfare of the natives of the Union". ${ }^{25}$ The Act abolished individual land ownership by black people and introduced trust tenure through the creation of the South African Development Trust, which was a government body responsible for purchasing land in "released areas" for black settlement. ${ }^{26}$

produce of that land, or any valuable consideration of any kind whatever other than his own labour or services or the labour or services of his family".

20 Section 2(1)(a) of the Natives Land Act. For a discussion of the Natives Trust and Land Bill, see SAIRR Native Bills 1-35.

21 Section 2(1)(a) of the Natives Land Act.

22 Rugege 2004 Int'l J Legal Info 284.

23 Davenport 1985 Acta Juridica 61. Contracts of this type were agreements between the white landowner and farm workers in terms of which the farm workers were allowed to use a portion of the farmer's land for their own production and in return the farm workers would provide a certain amount of labour. Davenport 1987 Development Southern Africa 396 notes that the Land Act had a crippling effect on black agriculture. The Act was gazetted on 19 June 1936 in the Extraordinary Gazette No 2362. Although the Act later became known as the Development Trust and Land Act, s 51 of Act as gazetted, indicates that the Act shall be called the Native Trust and Land Act.

25 Section 4(1) of the Natives Trust and Land Act.

26 Robinson 1997 Brooklyn J Int'l L 475; Davenport 1985 Acta Juridica 65. For a discussion of the practical workings of the Trust, see Du Plessis 1991 THRHR 444-450. 
In terms of section 2(1) of the Act, certain areas of land (including land identified in the Natives Land Act) were transferred to the Native Trust to be administered by the Trust. Vested in the Trust was land reserved for the occupation of natives and land within the scheduled native areas as identified in the Natives Land Act. ${ }^{27}$ The South African Native Trust Fund ${ }^{28}$ was created and the funds utilised to acquire and develop land of the Trust, to advance the interest of natives in scheduled native areas, and to generally assist and develop the "material, moral and social wellbeing of natives" residing on Trust land. ${ }^{29}$ The Act further empowered the Trust to acquire land for native settlement, but limited the amount of land that could be acquired in this regard to approximately $13 \%$ of the total land. ${ }^{30}$ The land which could be acquired by the Trust was further limited to land within the scheduled native areas or within released areas. ${ }^{31}$ The Act created "reserves" for black people and increased the $8 \%$ of land reserved by the Natives Land Act to $13 \%$, confining $80 \%$ of the population to this area. ${ }^{32}$ In order to achieve the objectives of the Act, section 13 empowered the trustees of the Trust to expropriate land owned by natives outside a scheduled area for reasons of public health or for any other reason which would promote public welfare or be in the public interest. Compensation paid upon expropriation was determined by the fair market value of the land without any improvements, plus the value of the necessary or useful improvements; plus the value of luxurious improvements (limited to the actual cost of such improvements) plus a sum compensating for inconvenience. ${ }^{33}$

From the above it is clear that the Native Trust and Land Act was an important instrument used by the then government to facilitate its policy of racial segregation.

27 Section 6(1) of the Natives Trust and Land Act. See Van der Walt 1991 THRHR 739-742 for a discussion of the scope and content of the Land Acts.

28 A fund created in terms of $\mathrm{s} 8$ of the Natives Trust and Land Act.

29 Section 9(1) of the Natives Trust and Land Act.

30 It should be noted that this percentage reflected the position in 1936 and as time lapsed, the percentage was increased through initiatives such as the creation of the former homelands.

31 Section 10(2) of the Natives Trust and Land Act. Natives were entitled in terms of ss 11(1) and 18 (2) of the Act to purchase, lease or otherwise acquire land in scheduled areas (see Van der Merwe 1989 TSAR 679.

32 Robinson 1997 Brooklyn J Int'l L 475.

33 Section 13(4) of the Natives Trust and Land Act. 
The Act stripped black South Africans of their right to own land or even to live outside demarcated areas without proper authorization by the relevant authorities. It is clear that this Act furthered the objective of racial segregation, which eventually necessitated the need for land reform.

\subsection{The Group Areas Act 41 of $1950^{34}$}

The Group Areas Act of 1950, described as the "second wave" of evictions, ${ }^{35}$ was used by the then National Party government to forcibly remove black, coloured and Indian people from designated "white areas". ${ }^{36}$ According to Schoombee ${ }^{37}$

[g]roup areas legislation functions essentially through the control of ownership of immovable property, and of the occupation and "use" of land and premises, on the basis of race.

The aim of the Act was to provide for the establishment of group areas and for the control of the acquisition of immoveable property and the occupation of land and premises. ${ }^{38}$ The Act established three groups of people - a white group, a native group and a coloured group. ${ }^{39}$ Based on the creation of these groups, the Act made provision for the establishment of group areas designated for the exclusive use and ownership of members of a particular group. ${ }^{40}$ Disqualified persons - persons who were not of the same group as the group area - were not permitted to occupy any land or premises in a group area except under the authority of a permit, ${ }^{41}$ nor were

\footnotetext{
34 Hereinafter referred to as the Group Areas Act of 1950.

35 Bosman Land Reform 3.

36 For a more detailed discussion of the Act, see Hiemstra Group Areas Act, Henochsberg Explanation of the Group Areas Act, Kirkwood Group Areas Act.

37 Schoombee 1985 Acta Juridica 77.

38 The Act also contained measures to ensure proper municipal administration in certain areas ( $\mathrm{s}$ 7); restrictions on certain agreements relating to immovable property in controlled areas (s 8); restrictions on the occupation of land in controlled areas (s 10); and measures regarding the disposition of property held in contravention of the Act (s 20).

39 Section 2(1) of the Group Areas Act of 1950. A member of the coloured group is defined as a person who is not a member of the white or native groups.

40 Section 3(1) of the Group Areas Act of 1950.

41 Section 4(1) of the Group Areas Act of 1950.
} 
they permitted to own immoveable property in an area from which they were disqualified. $^{42}$

\subsection{The Group Areas Act 36 of $1966^{43}$}

The final of the four Land Acts to be discussed in this section is the Group Areas Act of 1966, which complemented the Group Areas Act of $1950 .^{44}$ The aim of the Act was to consolidate the law related to the establishment of group areas and to regulate the control of the acquisition of immoveable property and the occupation of land and premises. ${ }^{45}$ The Act shows numerous similarities with the Group Areas Act of 1950 and also established three groups for the purposes of the Act: white, Bantu $^{46}$ and coloured groups. Section 13 of the Act prohibits the acquisition of immovable property in a controlled area, while section 20 placed restrictions on the occupation of land in a controlled area. ${ }^{47}$ These sections reflect sections 4 and 5 of the Group Areas Act of 1950. The Act also stated that ${ }^{48}$

no person who is a member of any group shall occupy and no person shall allow any such person to occupy any land or premises in a specified area which was not lawfully occupied ... except under the authority of a permit.

However, the Act did provide for exceptions where it would not be unlawful for a person to occupy land or premises if the person is a bona fide servant or employee of the state; or is a bona fide visitor for a total of not more than ninety days in any

42 Section 5(1) of the Group Areas Act of 1950. Any agreement allowing persons from outside a designated group to occupy or own property in an area not designated to them would be $a b$ initio null and void (s 18 of the Act). Hereinafter referred to as the Group Areas Act of 1966.

44 For an outline of the Act, see Schoombee 1985 Acta Juridica 77-84.

45 Long-title of the Group Areas Act of 1966. For a discussion of the origins and status of the Group Areas Act of 1966, see Omar 1989 De Rebus 515-522. For a general discussion of the Act, see Rutsch 1991 South African Human Rights and Labour Law Yearbook 98-103; Davis and Corder 1990 SA Public Law 157-168.

46 The Act moved away from the use of the word "native" and used the term "Bantu" to refer to "any person who in fact is or who is generally accepted as a member of an aboriginal race or tribe in Africa" (s12(1)(b)(i) of the Group Areas Act of 1966).

47 The Act formed the basis of separate development, especially in residential areas (Van der Walt 1990 De Jure 26).

48 Section 17(1) of the Group Areas Act of 1966. 
calendar year of any person lawfully residing on the land or premises; or is a bona fide scholar attending a school controlled or aided by the state. ${ }^{49}$

In furtherance of its policy of racial segregation, section 23 of the Act empowered the then State President to proclaim though the Government Gazette an area for the exclusive occupation by or ownership of members of a specified group. In conjunction with section 23, sections 26 and 27 prohibited the occupation or acquisition of property by disqualified persons in group areas. Regarding the enforcement of the Act, the then South African Police Force were given extensive powers. As an example of these powers, section 43(1)(a) empowered the Police, when investigating a suspected offence in terms of the Act, to enter without a warrant any premises and make any examination as might be necessary.

It was estimated that between 1960 and 1983 approximately 3.5 million people were forcibly removed as a result of the Acts discussed in the previous four paragraphs. $^{50}$

From the discussion of these Land Acts, it is evident that the effects of these Acts are morally and practically unacceptable and that the Acts had to be repealed in order to achieve a more equal distribution of land ownership. The following section will provide a brief overview of the measures taken between 1991 and 1997, which were aimed at addressing the inequalities brought about by the Land Acts.

Section 17(2) of the Group Areas Act of 1966.

Platzky and Walker Surplus People 9-12; Robinson 1997 Brooklyn J Int'l L 477, Department of Land Affairs White Paper para 2.5. 


\section{$3 \quad$ Measures between 1991 and 1997}

\subsection{The Abolition of Racially Based Land Measures Act 108 of 1991}

After the disbanding of the African National Congress and the release of Nelson Mandela, the National Party government of FW de Klerk had to affect measures to end the centuries of apartheid - a system supported by the Land Acts discussed in the preceding paragraphs. The Abolition of Racially Based Land Measures Act was promulgated in order to bring an end to the Land Acts, and came into operation on 30 June $1991 .{ }^{51}$ According to the long title of the Act, it was promulgated to

repeal or amend certain laws so as to abolish certain restrictions based on race or membership of a specific population group on the acquisition and utilization of rights to land; to provide for the rationalization or phasing out of certain racially based institutions and statutory and regulatory systems repealed the majority of discriminatory land laws ...

In order to achieve this aim, section 1 of the Act repealed the Natives Land Act and related laws, while section 11 repealed the Natives Trust and Land Act. Section 12 of the Act contained transitional measures regarding the phasing out of the South African Development Trust. Since the Trust owned the majority of "native" land, transitional measures had to be put in place to facilitate the transfer of the land out of the Trust to other state departments or institutions established to take transfer of the land.

Section 48 of the Act dealt with the repeal of the Group Areas Act of 1966. In terms of this section, the Group Areas Act of 1966 and all amendments thereto were abolished with immediate effect enabling all South Africans, regardless of race, to occupy and own land in any part of the country without fear of prosecution. For the first time in almost 80 years non-white South Africans were no longer precluded from owning land. This signalled an end to an unfortunate chapter in South Africa's history.

51 For a discussion of the Act including the identification of certain problems that the Act faced, see Olivier, Du Plessis and Pienaar 1991 SA Public Law 115-125; Du Plessis, Olivier and Pienaar 1991 SA Public Law 264-266. 


\subsection{The Reconstruction and Development Programme (RDP)}

The first democratically elected government inherited a country ravaged by extreme levels of poverty, a worsening unemployment problem and unacceptable inequalities in levels of income. ${ }^{52}$ In 1994 the Reconstruction and Development Programme (RDP) introduced an integrated socio-economic policy framework ${ }^{53}$ aimed at eradicating the legacies of the past through the redress of inequalities and building a vibrant and democratic South Africa. The reasons for introducing the RDP included the fact that South Africa was identified as a country with one of the highest income distribution inequalities and consequently an extremely high incidence of poverty. ${ }^{54}$ The RDP recognised that poverty was the single worst burden on the country and that poverty affected millions of people, especially those living in rural areas. ${ }^{55}$ In order to address poverty and extreme deprivation, the programme identified various aspects that needed to be addressed. These included the provision of land and housing, as well as access to safe water and sanitation. ${ }^{56}$

The programme recognised that the basic needs of people had to be met and that human resource development should take place. In order to eradicate poverty and

52 Aliber Poverty-eradication 17. For an overview of the RDP, see Turok 1995 Int J Urban Reg Res 305-318; De Wet 1994 S Afr J Econ 307-332. For a discussion of the initial reaction of the business sector to the RDP, see Godsell 1994 SALB 44-47 and for the reaction of labour organisations, see Erwin 1994 SALB 39-43.

53 The RDP was the first policy articulation of the new national government. Turok 1995 Int J Urban Reg Res 305 described the RDP as the centrepiece of the government's efforts to promote socioeconomic reform and restructuring. He further described the RDP as "a bold umbrella-plan that aims to bring about all-round socio-economic improvement; to focus the efforts of different levels and departments of government on this task; and to make the process thoroughly participatory by mobilizing the resources of civil society to support it" (Turok 1995 Int J Urban Reg Res 305).

54 White Paper on Reconstruction and Development in Gen N 1954 in GG 16085 of 23 November 1994 (hereinafter referred to as the RDP White Paper).

55 The problem statement to the RDP indicated that it was estimated in 1994 that at least 17 million people were living below the Minimum Living Level (what does this mean and how is it measured) and of these that at least 11 million were in rural areas (ANC Basic Guide para 2.2.1).

56 The elimination of illiteracy and an improvement in the quality of education was also identified. It is interesting to note that the RDP White Paper and the ANC Basic Guide differ substantially from each other. As an example, the RDP White Paper focussed less on land reform and referred to land reform pilot projects only, while the Basic Guide placed substantial emphasis on land reform. 
ensure that the basic needs of the poor were met, the programme identified a strategy resting on four pillars, which were:

- $\quad$ creating opportunities for all South Africans to develop to their full potential;

- boosting production and household income through job creation, productivity and efficiency, improving conditions of employment, and creating opportunities for all to sustain themselves through productive activity;

- $\quad$ improving living conditions through better access to basic physical and social services, health care, and education and training for urban and rural communities; and

- $\quad$ establishing a social security system and other safety nets to protect the poor, the disabled, the elderly and other vulnerable groups. ${ }^{57}$

The programme acknowledged that land represented the most basic need for the rural population, a need that resulted from the discriminatory practices of the past regime. In order to effectively address the issues of inequality, poverty and landlessness caused by the "injustices of forced removals and the historical denial of access to land"58 the programme identified the need for the establishment of a comprehensive national land reform programme. ${ }^{59}$ The RDP envisaged $^{60}$

a dramatic land reform programme to transfer land from the inefficient, debtridden, ecologically-damaging and white-dominated large farm sector to all those who wish to produce incomes through farming in a more sustainable agricultural system.

57 ANC Basic Guide para 2.2.4. The government's commitment to addressing these pillars is evident from the legislation that has been enacted since the introduction of the programme. These include the Employment Equity Act 55 of 1998 and the Skills Development Act 97 of 1998. These legislative measures are aimed at creating opportunities for all South Africans to develop to their full potential and at providing them with access to land in order to sustain themselves through productive activity.

ANC Basic Guide para 2.4.2. For a discussion of the initial approach of the ANC to land reform, see Levin and Weiner "Politics of Land Reform" 107-110.

59 Boyle 2001 II\&CLR 677. For a discussion of the land reform programme in the context of the RDP, see Deininger and May Can There be Growth With Equity 7-10.

60

ANC Basic Guide para 4.3.8. 
The land reform programme (as envisaged by the RDP) is aimed at encouraging the use of land for agricultural purposes and providing productive land in order to raise income and productivity. The reform programme is based on the redistribution of land to those who need it, but cannot afford it and on restitution for those who were deprived of their land due to the system of apartheid. ${ }^{61}$ In the light of these inequalities, the RDP identified the main elements of land reform: land redistribution, restitution, and tenure reform. ${ }^{62}$

The aim of the land redistribution programme was to strengthen the property rights of communities already occupying the land and to provide access to land for those previously deprived of the right to be the owners of land. Within the context of redistribution, the RDP set the ambitious target of transferring $30 \%$ of all whiteowned agricultural land to black South Africans by $2001 .^{63}$ The aim of land restitution was to restore land to South Africans dispossessed by discriminatory legislation and practices since $1913 .{ }^{64}$ In order to achieve these aims the government needed to provide substantial funding and to create an infrastructure that supported land development. ${ }^{65}$ As a result of the discriminatory practices of the past, the majority of South Africans had been dispossessed of their land and in instances forcibly removed and relocated. ${ }^{66}$ The RDP recognised this and indicated

61 ANC Basic Guide para 2.4.5. Van Rooyen, Ngqangweni and Njobe 1994 Agrekon 257 note that the RDP struck a nerve in South African society with its emphasis on land restitution and redistribution.

62 Aliber and Mokoena "Land Question" 330.

63 ANC Basic Guide para 2.4.14. As early as 1994 Van Rooyen, Ngqangweni and Njobe 1994 Agrekon 260 questioned how realistic the 30\% transfer was, given the scarcity of resources to support the programme. The authors also noted that within the context of the agricultural sector, the objectives and targets of the RDP would have to be balanced with other national economic needs such as the importance of productive land use for agriculture and food production and in this regard they stressed the importance of the provision of support services and policies to support productive and sustainable land use (Van Rooyen, Ngqangweni and Njobe 1994 Agrekon 257.

64 It should be noted that restitution was originally conceived as a limited programme that focussed on redress rather than the wider concept of agrarian restructuring (Hall 2004 Canadian Journal of African Studies 656).

65 Substantial funding is required both to purchase land to redistribute, or to restore land where the owners were dispossessed, and to provide financial compensation in cases where it is not possible to restore land to its original owners.

66 Forced removals were to a large extent carried out in terms of the Prevention of Illegal Squatting Act 52 of 1951 . The Act was aimed at preventing illegal squatting and made provision for the removal of persons who transgressed the Act and certain instances the demolition of structures 
that the need existed to restore land to the dispossessed through implementing a system of land restitution. ${ }^{67}$

A key element in the fight against poverty is the development of human resources. The central objective of the entire RDP was to provide opportunities for people to develop themselves in order not only to improve the quality of their own lives, but also to contribute to the upliftment of their communities. The programme acknowledged the fact that although the ultimate responsibility for ensuring human resource development lay with government, civil society (by implication, the private sector) should be encouraged to actively take part in the provision of learning opportunities. $^{68}$

The Reconstruction and Development Programme represented a very important first step in post-apartheid South Africa en route to initiating change and addressing the injustices of the past. The programme identified the eradication of poverty as its most important challenge. ${ }^{69}$ In order to eradicate poverty the basic needs of those disadvantaged by apartheid needed to be addressed. These needs were to be addressed inter alia through programmes of land reform and land redistribution, as well as the development of human resources. In order to further address the issue of land reform, the White Paper on Land Policy, $1997^{70}$ was

erected in contravention of the Act. For a discussion of this Act, see Lewis 1989 SAJHR 233-239; O'Regan 1989 SAJHR 361-394.

67 ANC Basic Guide para 2.4.13. The issue of land restitution was confirmed in s 25(7) of the Constitution in terms of which "a person or community dispossessed of property after 19 June 1913 as a result of past racially discriminatory laws or practices is entitled, to the extent provided by an Act of Parliament, either to restitution of that property or equitable redress".

The programme also identified the need to address Adult Basic Education and Training (ABET), which was aimed at providing adults with literacy and numeracy skills. Other issues covered by the programme included the environment, nutrition and healthcare, building the economy and democratising the state and society. This study will, however, be limited to matters dealing with land and skills development. Although it will be evident from the discussions to follow that the RDP (with reference to land reform) and other land reform policies have not been as successful as initially envisaged, the RDP has been successful in other areas, where millions of black South Africans have gained access to clean running water, housing and electricity (Harsch 2001 Africa Recovery 14).

69 It should be noted that the eradication of extreme poverty and hunger (by 2015) is the first of the Millennium Development Goals to which South Africa subscribed.

70 Department of Land Affairs White Paper (hereinafter referred to as the White Paper). It should be noted that this important policy instrument was not published in the Government Gazette, 
released with the specific vision of establishing a land policy which is "just, builds on reconciliation and stability, contributes to economic growth and bolsters household welfare". ${ }^{71}$ The following paragraphs will provide a brief discussion of this policy instrument.

\subsection{The White Paper on Land Policy, 1997}

The White Paper was responsible for establishing the overall land reform policy and it addressed inter alia the injustices caused by racially-based land dispossessions, unequal land ownership, and the need for the sustainable use of land. ${ }^{72}$ In this regard the White Paper ${ }^{73}$ acknowledged:

Forced removals in support of racial segregation have caused enormous suffering and hardship in South Africa and no settlement of land issues can be reached without addressing such historical injustices.

Based on this reality, the aim of the White Paper was meant to provide an overall platform for land reform consisting of three principal components: restitution, redistribution and tenure reform - the same three pillars as identified in the RDP. ${ }^{74}$ Government committed itself to a land reform programme where, with specific reference to redistribution, it would not intervene in the land market. Rather than getting directly involved in the purchase of land for redistribution, the government undertook to adhere to the principle of "willing buyer, willing seller", where government would provide resources to finance market-led redistribution

which is the normal route that policy instruments follow once a Green Paper has been released. In this regard a Green Paper was not released, and accordingly the White Paper on Land Policy, 1997 cannot be described as a true White Paper that went through normal administrative processes.

71 Department of Land Affairs White Paper para 2.1.

72 Department of Land Affairs White Paper para 2.1. The White Paper noted that an effective land policy should also deal with the need to reduce poverty and enhance economic growth. See Mbao 2002 JJS 94.

73 Department of Land Affairs White Paper para 3.17. For a discussion of the White Paper as a policy document for redistribution, see Carey Miller and Pope Land Title 399-402.

74 See Mostert, Pienaar and Van Wyk "Land" 117. 
transactions without government becoming the owner of the land. ${ }^{75}$ However, in the recent past government has identified the "willing buyer, willing seller" system as one of the principal obstacles against redistribution and is considering abolishing the principle and moving towards a more aggressive approach of expropriation. ${ }^{76}$ The White Paper ${ }^{77}$ recognised the reality that it had limited fiscal resources to finance the land reform programme, and that the land reform budget is competing with other budgetary priorities such as housing, health care and education. ${ }^{78}$

As stated above, the White Paper confirmed the three pillars of the land reform programme. With reference to redistribution, the White Paper $^{79}$ stated that

the purpose of the land redistribution programme is to provide the poor with access to land for residential and productive uses, in order to improve their income and quality of life.

From a sustainability perspective, the White Paper $^{80}$ clearly stated, with reference to redistribution projects:

75 This approach to land reform has been described as market-led or market-assisted agrarian reform (Lahiff 2007 Third World Quarterly 1577). For a discussion of the origins of market-led agrarian reform and recent debates, see Lahiff, Borras and Kay 2007 Third World Quarterly 1420-1423.

76 The Green Paper on Land Reform proposes a move away from the "willing buyer, willing seller" principle. It should be noted that although the government identifies the principle as one of the major stumbling blocks in the current land policy, it has not provided the details of any research conducted to support its position. It has been argued that redistributive land reform has two minimum requirements namely "compensation to landlords at below 'market' price and payment by peasants and workers at below actual acquisition cost" (Borras 2006 Journal of Agrarian Change 75). These requirements would provide support for the Government's proposed move away from the "willing buyer, willing seller" principle. Borras 2006 Journal of Agrarian Change 74-75 is of the opinion that instances where current owners of land are paid $100 \%$ of the market value while buyers shoulder $100 \%$ of the acquisition cost cannot be described as true redistributive land reform. However, if the South African position is examined it would become evident that land reform beneficiaries are seldom responsible for $100 \%$ of the acquisition cost. In terms of an elaborate grant system, beneficiaries are supported through government funding to purchase land. See Kloppers Improving Land Reform 66-74 for a discussion of the government measures to foster the conditions in which prospective beneficiaries may gain access to land.

77 Department of Land Affairs White Paper para 3.2.

78 Given the limited resources allocated to the land reform programme it is not surprising that the pace of progress of the land reform programme has been very slow. With an annual budget of less than $1 \%$ of the national budget, budgetary evidence does not support the identification of land reform as a priority.

79 Department of Land Affairs White Paper para 4.3. The redistribution programme will be discussed in more detail in para 2.3.1. 
Viability and sustainability of projects must be ensured by giving attention to: the economic and social viability of intended land use; fiscal sustainability by the local authority; environmental sustainability; proximity and access to markets and employment; availability of water and bulk infrastructure.

Viability and sustainability are central to any successful land reform programme. Unfortunately, the issue of the economic and social viability of the intended land use has been largely neglected in both the redistribution and restitution pillars with the majority of agricultural land reform programmes being unproductive.

The goal of the restitution programme, on the other hand, is described as ${ }^{81}$

to restore land and provide other restitutionary remedies to people dispossessed by racially discriminatory legislation and price, in such a way as to provide support to the vital process of reconciliation, reconstruction and development.

The White Paper reaffirms the fact that the policy and procedure for land claims are based on the provisions of section 25(4) of the Constitution and the Restitution of Land Rights $A c t^{82}$ and details four of its elements: qualification criteria, ${ }^{83}$ forms of restitution, ${ }^{84}$ compensation, ${ }^{85}$ and urban claims. ${ }^{86}$

Although land reform aims to contribute to economic development, both by providing beneficiaries with the opportunity to engage in productive land use and by increasing employment opportunities through encouraging greater investment,

80 Department of Land Affairs White Paper para 4.7.1. See Pienaar 2011 PER 34; Carey Miller and Pope Land Title 400.

81 Department of Land Affairs White Paper para 4.13. The White Paper reaffirms the criteria for the lodgement of a restitution claim and identifies some of the legislation that will be recognised as racially discriminatory laws for the purposes of the restitution process (Department of Land Affairs White Paper para 4.14.2). The restitution programme will be discussed in more detail in para 2.3.2.

82 Restitution of Land Rights Act 22 of 1994. For further reference to this Act, see para 2.4.1.

83 Department of Land Affairs White Paper para 4.14.2. Dispossession of right in land after 19 June 1913 in terms of, or furthering the objective of, a discriminatory law or practice without receiving equitable and just compensation.

Department of Land Affairs White Paper para 4.14.4. Forms of restitution include: restoration of the dispossessed land; provision of alternative land; payment of compensation; or a combination of land and compensation.

85 Department of Land Affairs White Paper para 4.14.5. The White Paper addresses the payment of compensation to claimants and compensation to land owners.

86 Department of Land Affairs White Paper para 4.14.6. 
the majority of agricultural land reform projects are not using land productively and the envisaged growth in employment has not materialised. ${ }^{87}$ In the most instances the major cause for the unproductive use of land is a lack of financial and institutional support from government to land reform beneficiaries. This is despite the White Paper's ${ }^{88}$ acknowledgement that without a programme of state support and targeted intervention, land reform will not be possible and that

[t]he long-term success and sustainability of the land reform programme is to a large extent dependent on the ability of potential beneficiaries to be able to access the programme easily, and to have a clear understanding of what assistance they can get from government.

This passage underlines the critical importance of post-settlement support for the success and sustainability of the land reform programme. Unfortunately it appears as though the importance of post-settlement support has in the past been sacrificed for the numbers game, in which the focus was on the number of restitution claims settled or the number of hectares transferred in terms of the redistribution programme, rather than on ensuring that the transfers resulted in sustainable livelihoods for the beneficiaries.

\section{Conclusion}

The most prominent instrument used by the apartheid regime to establish and enforce its policy of racial segregation was legislative intervention. This article highlighted a number of the most significant legislative measures put in place to limit the black majority's ownership of land, especially agricultural land. Through its limitation on land ownership, the then government confined the majority of the population to a few homelands in which ownership was permitted. The result of these measures is that South Africa currently has extremely skewed land ownership

87 This is despite the fact that the White Paper identifies redistributive land reform and the provision of support services as central to the government's employment strategy and to reducing the mounting cost of the welfare budget (Department of Land Affairs White Paper para 2.5.2). 
and land use patterns where historically disadvantaged South Africans do not own the majority of the productive agricultural land. This situation resulted in the need for a comprehensive land reform programme as envisaged by the RDP and the White Paper and eventually endorsed by the Constitution. Unfortunately, the land reform programme has had limited success and further legislative interventions, such as forced expropriations, might become necessary. However, in order to enable forced expropriations an amendment to the Constitution will be required, and it remains to be seen whether the current regime will choose to change the constitutionally protected property clause - a clause that was central to the negotiations that lead to the current political dispensation. 


\section{Bibliography}

Aliber Poverty-eradication

Aliber M Poverty-eradication and Sustainable Development (HSRC Cape Town 2002)

Aliber and Mokoena "Land Question"

Aliber M and Mokoena R "The Land Question in Contemporary South Africa" in

Daniel J, Habib A and Southall R (eds) State of the Nation: South Africa 20032004 (HSRC Cape Town 2003) 330-348

ANC Basic Guide

African National Congress $A$ Basic Guide to the Reconstruction and Development Programme (ANC Pretoria 1994)

Badenhorst, Pienaar and Mostert Law of Property

Badenhorst P, Pienaar J and Mostert H Silberberg and Schoeman's The Law of Property $5^{\text {th }}$ ed (LexisNexis Durban 2006)

Borras 2006 Journal of Agrarian Change

Borras SM "The Philippine Land Reform in Comparative Perspective: Some Conceptual and Methodological Implications" 2006 Journal of Agrarian Change 69-101

Bosman Land Reform

Bosman F Land Reform: A Contextual Analysis (FW de Klerk Foundation Johannesburg 2007)

Boyle 2001 II\&CLR

Boyle $\mathrm{H}$ "The land problem: what does the future hold for South Africa's land reform program?" 2001 II\&CLR 665-696 
Carey Miller and Pope Land Title

Carey Miller D and Pope A Land Title in South Africa (Juta Cape Town 2000)

\section{CDE Land Reform}

Centre for Development and Enterprise Land Reform in South Africa - A $21^{\text {st }}$ Century Perspective (Centre for Development and Enterprise Johannesburg 2005)

Claxton 2003 Mich J Race \& L

Claxton $\mathrm{H}$ "Land and liberation: Lessons for the creation of effective land reform policy in South Africa" 2003 Mich J Race \& L 529-552

Davenport 1985 Acta Juridica

Davenport $\mathrm{T}$ "Some reflections on the history of land tenure in South Africa, seen in the light of attempts by the State to impose political and economic control" 1985 Acta Juridica 53-76

Davenport 1987 Development Southern Africa

Davenport T "Can sacred cows be culled? A historical review of land policy in South Africa, with some questions about the future" 1987 Development Southern Africa 388-400

Davenport 1990 Development Southern Africa

Davenport $T$ "Land legislation determining the present racial allocation of land" 1990 Development Southern Africa 431-440

Davis and Corder 1990 SA Public Law

Davis D and Corder H "Restructuring the rural economy: Legal issues" 1990 SA Public Law 157-168 
De Wet 1994 S Afr J Econ

De Wet G "The RDP and a structural problem in the South African economy" 1994 S Afr J Econ 307-332

Deininger and May Can There be Growth with Equity

Deininger K and May J Can There be Growth with Equity: An Assessment of Land Reform in South Africa (World Bank Development Research Group Washington 2000)

Department of Land Affairs White Paper

Department of Land Affairs White Paper on Land Policy, 1997 (DLA Pretoria 1997)

Du Plessis 1991 THRHR

Du Plessis W "Dorpstigting: SAOT en selfregerende gebiede" 1991 THRHR 444-457

Du Plessis, Olivier and Pienaar 1991 SA Public Law

Du Plessis W, Olivier N and Pienaar J "Nuwe grondmaatreëls" 1991 SA Public Law 255-269

Erwin 1994 SALB

Erwin A "The reconstruction and development programme: a view from the tripartite alliance" 1994 SALB 39-43

Feinberg 1993 IJAHS

Feinberg H "The Natives Land Act of 1913 in South Africa: Politics, race and segregation in the early 20th century" 1993 IJAHS 65-109

Feinberg 1995 Historia

Feinberg $\mathrm{H}$ "Pre-Apartheid African land ownership and the implication for the current restitution debate in South Africa" 1995 Historia 48-63 
Feinberg 2009 Journal for Contemporary History

Feinberg H "Black South African initiatives and the land: 1913-1948" 2009 Journal for Contemporary History 39-61

Feinberg and Horn 2009 Journal of African History

Feinberg $\mathrm{H}$ and Horn $\mathrm{A}$ "South African territorial segregation: New data on African farm purchases, 1913-1936" 2009 Journal of African History 41-60

Fenyes, Van Rooyen and Vink 1990 Development Southern Africa

Fenyes T, Van Rooyen C and Vink N "Reassessment of the Land Acts of 1913 and 1936" 1990 Development Southern Africa 583-589

Godsell 1994 SALB

Godsell B "The reconstruction and development programme: A view from business" 1994 SALB 44-47

Hall 2004 Canadian Journal of African Studies

Hall R "Land restitution in South Africa: Rights, development, and the restrained State" 2004 Canadian Journal of African Studies 654-671

Harsch 2001 Africa Recovery

Harsch E "South Africa tackles social inequities" 2001 (Jan) Africa Recovery $12-18$

Henochsberg Explanation of the Group Areas Act

Henochsberg E An Explanation of the Group Areas Act, 1950 (Butterworth Durban 1950)

Hiemstra Group Areas Act

Hiemstra V The Group Areas Act (Juta Cape Town 1953) 
Kirkwood Group Areas Act

Kirkwood K The Group Areas Act - An Analysis (SAIIR Johannesburg 1950)

Kloppers Improving Land Reform

Kloppers HJ Improving Land Reform Through CSR: A Legal Framework Analysis (LLD-thesis NWU 2012)

Lahiff 2007 Third World Quarterly

Lahiff E "'Willing buyer, willing seller': South Africa's failed experiment in market-led agrarian reform" 2007 Third World Quarterly 1577-1597

Lahiff, Borras and Kay 2007 Third World Quarterly

Lahiff E, Borras S and Kay C "Market-led agrarian reform: policies, performance and prospects" 2007 Third World Quarterly 1417-1436

Levin and Weiner "Politics of Land Reform"

Levin R and Weiner D "The Politics of Land Reform in South Africa After Apartheid: Perspectives, Problems, Prospects" in Bernstein H The Agrarian Question in South Africa (Frank Cass \& Co London 1996) 93-119

Lewis 1989 SAJHR

Lewis C "The Prevention of Illegal Squatting Act: The promotion of homelessness?" 1989 SAJHR 233-239

Mapadimeng 2003 Transformation

Mapadimeng $M$ "The Land Redistribution for Agricultural Development (LRAD) sub-programme: Opportunity for or constraint to land redistribution, rural economic development and poverty alleviation?" 2003 Transformation 20-41 
Mbao 2002 JJS

Mbao $M$ "Undoing the injustices of the past: Restitution of rights in land in post-apartheid South Africa with special reference to the North-West Province" 2002 JJS 88-114

Mostert 2002 SALJ

Mostert H "Land restitution, social justice and development in South Africa" 2002 SALJ 400-428

Mostert, Pienaar and Van Wyk "Land"

Mostert H, Pienaar J and Van Wyk J "Land" in Joubert W (ed) The Law of South Africa Vol 14(1) $2^{\text {nd }}$ ed (LexisNexis Durban 2010) $1-261$

Murray and Williams 1994 Review of African Political Economy

Murray C and Williams G "Land and Freedom in South Africa" 1994 Review of African Political Economy 315-324

Olivier, Du Plessis and Pienaar 1991 SA Public Law

Olivier N, Du Plessis W and Pienaar J "Wette op grondbesit herroep" 1991 SA Public Law 115-125

Omar 1989 De Rebus

Omar I "The Group Areas Act: A historical and legal overview" 1989 De Rebus 515-522

\section{O'Regan 1989 SAJHR}

O'Regan C "No more forced removals? An historical analysis of the Prevention of Illegal Squatting Act" 1989 SAJHR 361-394

Pienaar 2011 PER

Pienaar J "Restitutionary road: Reflecting on good governance and the role of the land claims court" 2011 PER 30-48 
Platzky and Walker Surplus People

Platzky L and Walker C The Surplus People: Forced Removals in South Africa (Ravan Press Johannesburg 1985)

Robinson 1997 Brooklyn J Int'l L

Robinson L "Rationales for rural land redistribution in South Africa" 1997 Brooklyn J Int'l L 465-504

Rugege 2004 Int'l J Legal Info

Rugege S "Land reform in South Africa: An overview" 2004 Int'l J Legal Info 283-312

Rutsch 1991 South African Human Rights and Labour Law Yearbook

Rutsch P "The Group Areas Act" 1991 South African Human Rights and Labour Law Yearbook 98-103

SAIRR Native Bills

South African Institute of Race Relations The Native Bills Described and Analysed(SAIRR Johannesburg 1935)

Schoombee 1985 Acta Juridica

Schoombee J "Group areas legislation - The political control of ownership and occupation of land" 1985 Acta Juridica 77-107

Turok 1995 Int J Urban Reg Res

Turok I "Restructuring or reconciliation? South Africa's Reconstruction and Development Programme" 1995 Int J Urban Reg Res 305-318

Van der Walt 1990 De Jure

Van der Walt AJ "Towards the development of post-apartheid land law: An exploratory survey" 1990 De Jure 1-46 
Van der Walt 1991 THRHR

Van der Walt AJ "Land law without the land acts - Predicaments and possibilities" 1991 THRHR 738-752

Van der Merwe 1989 TSAR

Van der Merwe D "Land tenure in South Africa: A brief history and some reform proposals" 1989 TSAR 663-692

Van Rooyen, Ngqangweni and Njobe 1994 Agrekon

Van Rooyen J, Ngqangweni S and Njobe B "Agricultural change, reconstruction and development in South Africa: Comments on the RDP" 1994 Agrekon 257-260

Wickins 1981 S Afr J Econ

Wickins P "The Natives Land Act of 1913: A cautionary essay on simple explanations of complex change" 1981 S Afr J Econ 105-129

\section{Register of case law}

Government of the Republic of South Africa v Grootboom 20011 SA 46 (CC)

Port Elizabeth Municipality v Various Occupiers 20051 SA 217 (CC)

\section{Register of legislation}

Abolition of Racially Based Land Measures Act 108 of 1991

Constitution of the Republic of South Africa, 1996

Employment Equity Act 55 of 1998

Group Areas Act 41 of 1950

Group Areas Act 36 of 1966

Natives Land Act 27 of 1913

Native Trust and Land Act 18 of 1936

Prevention of Illegal Squatting Act 52 of 1951 
Skills Development Act 97 of 1998

Restitution of Land Rights Act 22 of 1994

\section{Register of government publications}

Gen N 1954 in GG 16085 of 23 November 1994

\section{Register of internet sources}

SAPA 2010 www.politicsweb.co.za

SAPA 2010 90\% of Redistributed Farms Not Functional - Nkwinti www.politicsweb.co.za/politicsweb/view/politicsweb/en/page72308?oid=1635 15\&sn=Detail [date of use 19 Jun 2013]

\section{List of abbreviations}

ABET

Brooklyn J Int'l L

CDE

II\&CLR

IJAHS

Int'I J Legal Info

Int J Urban Reg Res

JJS

Mich J Race \& L

PER

RDP

SAIRR

SAJHR

SALB
Adult Basic Education and Training

Brooklyn Journal of International Law

Centre for Development and Enterprise

Indiana International \& Comparative Law Review

International Journal of African Historical Studies

International Journal of Legal Information

International Journal of Urban and Regional Research

Journal for Juridical Science

Michigan Journal of Race and Law

Potchefstroom Elektroniese Regstydskrif / Potchefstroom

Electronic Law Journal

Reconstruction and Development Programme

South African Institute of Race Relations

South African Journal on Human Rights

South African Labour Bulletin 
SALJ South African Law Journal

S Afr J Econ

South African Journal of Economics

THRHR

Tydskrif vir Hedendaagse Romeins Hollandse Reg

TSAR

Tydskrif van die Suid-Afrikaanse Reg / Journal of South African Law 